\title{
リファマイシンに関する研究
}

\author{
塚 本 悟 郎*・相 川 法 男**.田口 雅 裕*
}

\section{Studies on Rifamycins.}

\author{
Goro Tsukamoto*, Norio AIKawa** and Masahiro Taguchi ${ }^{*}$
}

\begin{abstract}
Rifamycins are important antibiotics. This article describes the studies on rifamycins; i ) the formation of dihydropyrimidorifamycins in the reaction of rifamycin $S$ with hexahydro-1,3,5-triazines, ii) the formation of dihydropyrimidorifamycins from 3-formylrifamycin S and 3-formylrifamycin SV, iii) the reduction of the iminium bond of dihydropyrimidorifamycins, and iv) the reaction of 3 -formylrifamycin $S$ with Schiff bases and aminomethylethers.
\end{abstract}

\section{1. はじめに}

1959 年, Sensi らは St. Raphael (フランス)の土から 分離した放線菌の培養液から抗生物質リファマイシン B （1）を単離した1)。1 は過酸化水素でリファマイシン $\mathrm{O}$ (2) に酸化され，2はアスコルビン酸で 1 に還元され る2。さらにSensi らは 1 と 2 の水溶液を放置しておく と抗菌活性が徐々に増大することを認め, 両水溶液中に リファマイシン S (3) が生成していることを見出し た3)。3はアスコルビン酸でリファマイシン SV ( 4 )に還 元され, 4 は過酸化水素で 3 に酸化される ${ }^{4)}$ 。1964 年, Prelog らは化学的分解による方法で 3 の構造を明らかに しだ)。同じ年, Brufani らはX線解析で 1 の $p$-ヨード アニリド誘導体の構造を明らかにしだ)。今日では種々 のリファマイシン誘導体のX 線解析がなされている7)。 1 は芳香族環に脂肪族鎖が橋状に置換した構造をとって いる。Prelog と Oppolzer は,このような構造の一連の 抗生物質をアンサマイシンと名づけた鼻。アンサ鎖 (ansa-chain) と称される脂肪族鎖の部分は近年不斉合成

* 鐘紡 (株) 薬品研究所合成研究部 (部)

** 鐘紡 (株) 薬品調査部

$$
\text { ( }
$$

* Section of Oraganic Chemistry, Pharmaceuticals Research Center, Kanebo, Ltd.

** Department of Patent, Pharmaceutical Division, Kanebo, Ltd.
の恰好の目標となっている ${ }^{9)}$ 。また，芳香族環部分に関 する報告もある ${ }^{10)}$ 。3 の全合成は 1980 年に岸らによっ て達成された の拡大および経口吸収性の改善をめざして, 1 3に種々 の化学的修飾をほどこし多くの誘導体を合成した ${ }^{12)}$ 。な かでもリファンピシン $(5)$ は経口吸収性に優れ, また結 核症に対して優れた効果を発揮することがわかり ${ }^{13)}$ ，今 日, 結核の特効薬として世に計り知れない貢献をしてい る。以下, リファマイシンの反応性に関する筆者らの知 見を紹介する。

\section{2. リファマイシンS（３）とへキサヒドロ- 1,3,5-トリアジン ( 6 ) との反応}

2.1. ジヒドロピリミドリファマイシンＭarsili ら

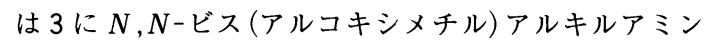
（7）を作用させると深青色のオキサジノリファマイシン 誘導体 ( 8 ) が生成すると報告している ${ }^{14)}$ 。

筆者らは $7 \mathrm{a}\left(\mathrm{R}^{\prime}=\mathrm{C}_{2} \mathrm{H}_{5}\right)$ を用いて Marsili らの反応を追 試し, 深青色の化合物 $A$ を得た。次に, 7 に替えてへキ

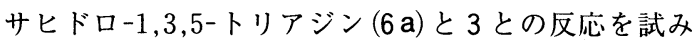
た。その結果, A と同一の深青色の化合物が得られた。 筆者らは当初, Marsili らに従って, A はオキサジノリ ファマイシン誘導体 8 aであると考えた。しかし以下に 述べるように，正しくはジヒドロピリミドリファマイシ ン誘導体 9 aであることがわかった ${ }^{15 \sim 17) 。 ~}$

2.2. 構造 Ferrari と Gallo は多数のリファマイシ ン誘導体のIR スペクトルを測定し, ( i ) キノン型リファ マイシンのフラノン $\nu_{\mathrm{C}(11)=0}$ は $1740 \mathrm{~cm}^{-1}$ 付近にあらわれ 


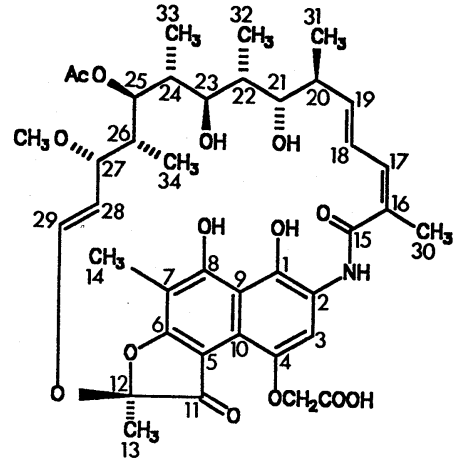

1: rifamycin $B$

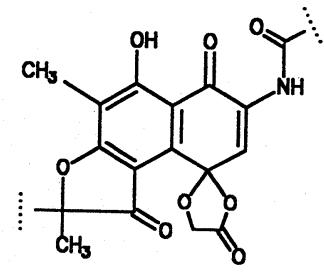

2: rifamycin 0<smiles></smiles>

3: rfamycin $S$<smiles>CC(=O)Nc1cc(O)c2c3c(c(C)c(O)c2c1O)OC(C)(C)C3=O</smiles>

4: rifamycin SV<smiles></smiles>

5: rifampicin

Fig. 1<smiles>[R]N1CN([R])CN([R])C1</smiles>

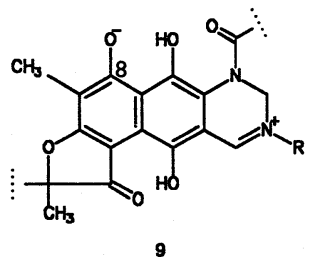

$\mathrm{R}-\mathrm{N}\left(\mathrm{CH}_{2} \mathrm{OR}\right)_{2}$

7

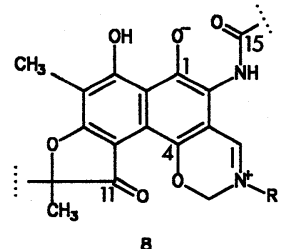

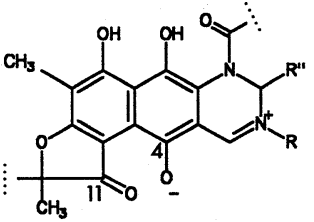

10

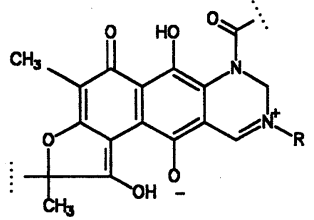

11

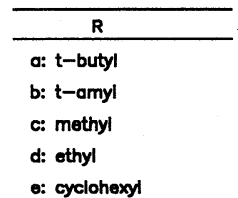

f: n-octyl

g: 8-octyl

h: t-octyl

i: 1-adamantyl

j: 1.1-dimethyl-

2-hydroxyethyl

Fig. 2

るがヒドロキノン型リファマイシンでは $1650 \mathrm{~cm}^{-1}$ 付近 にあらわれること，（ii）キノン型リファマイシンのアミ ド $\nu_{\mathrm{C}(15)=0}$ は $1700 \mathrm{~cm}^{-1}$ 付近にあらわれるがヒドロキノン 型リファマイシンでは $1650 \mathrm{~cm}^{-1}$ 付近にあらわれること を見出した ${ }^{18)}$ 。ヒドロキノン型リファマイシンでフラノ ン $\nu_{\mathrm{C}(11)=0}$ とアミド $\nu_{\mathrm{C}(15)=0}$ が低波数側にずれるのは分子 内水素結合 $\mathrm{C}(11)=\mathrm{O} \cdots \mathrm{HO}-\mathrm{C}(4), \mathrm{C}(1)-\mathrm{OH} \cdots \mathrm{O}=\mathrm{C}$ (15)による。ところで構造 8 にはこのような分子内水素 結合はあり得ない。従って $8 \mathrm{a}$ が A の正しい構造とする
ならば，Aのフラノン $\nu_{\mathrm{C}(11)=0}$ およびアミド $\nu_{\mathrm{C}(15)=0}$ はキ ノン型リファマイシンの場合と同じ波数領域にあらわれ る筈である。しかし，Aの 25-O-デアセチル誘導体Bの IR スペクトル $\left(\mathrm{CHCl}_{3}\right.$ 溶液 $)$ は 1740 および $1700 \mathrm{~cm}^{-1}$ 付 近には吸収を示さず， $1660 \mathrm{~cm}^{-1}$ 付近に強い吸収を示し た（Bを用いたのは $1740 \mathrm{~cm}^{-1}$ 付近にあらわれる 25 位ア セトキシ基の $\nu_{\mathrm{C}=0}$ を取り除くためである) ${ }^{16)}$ 。また, Maggi らが報告しているジヒドロピリミドリファマイシ ン誘導体 $10 \mathrm{~d}\left(\mathrm{R}^{\prime \prime}=\mathrm{CH}_{3}\right)$ の UV と ${ }^{1} \mathrm{H}-\mathrm{NMR}$ スペクトルが 
AとBのそれらに酷似していることがわかった。これら のことから AとBはオキサジン構造 $8 \mathrm{a}$ ではなくジヒド ロピリミジン構造 $10 \mathrm{a}\left(\mathrm{R}^{\prime \prime}=\mathrm{H}\right)$ をとっていると考えられ る。しかし構造 10 にはC $(11)=\mathrm{O} \cdots \mathrm{HO}-\mathrm{C}(4)$ の分子内 水素結合は存在せず, フラノン $\nu_{\mathrm{C}(11)=0}$ に関する IR が説 明できない。そこで，筆者らは10の構造を一部手直し してエノール構造 $11 \mathrm{a}$ を提案した ${ }^{15,16)}$ 。しかし, 最近B の ${ }^{13} \mathrm{C}-\mathrm{NMR}$ スペクトル $\left(\mathrm{CDCl}_{3}\right.$ 溶液 $)$ から 1 位はもとよ り 4 位のフェノール性水酸基も解離していないことがわ かった。即ち, $\delta 14.59$ および $\delta 16.44$ のプロトンをデ カップすると, 前者の場合 3 位と 10 位の炭素の多重度 が, また後者の場合 1 位と 2 位の炭素の多重度が変化し た。このことから， $\delta 14.59$ および $\delta 16.44$ のプロトン はそれぞれ 4 位および 1 位のフェノール性水酸基に帰属 される。従って AとBの正しい構造は 8 位のフェノール 性水酸基が解離したジヒドロピリミジン構造 $9 \mathrm{a}$ である と結論される ${ }^{17)}$ 。

2.3. 生成機構 ${ }^{17)} \quad 3$ と 6 a との反応を TLC で追跡す ると, 反応初期に中間体 $\mathrm{C}(=12 \mathrm{a})$ が生成しているのが 観察された。またTLC 分析により，Cはアスコルビン 酸でD (=13 a) に還元されること， Dは $\mathrm{MnO}_{2}$ で酸化さ れてCに復帰すること, $9 \mathrm{a} に \mathrm{NaBH}_{4}$ を作用させるとD が生成することが明らかになった。これらのことからC とDはそれぞれ $12 \mathrm{a}$ および $13 \mathrm{a} て ゙$ 示される構造をとっ ていると考えられる。一方, $14 \mathrm{a}$ に $6 \mathrm{a}$ を反応させると, $14 \mathrm{a}$ は直ちに消失してC $(=12 \mathrm{a})$ が生成し, 次いで $9 \mathrm{a}$ が生成するのが観察された。以上のことから $9 \mathrm{a}$ の生成 機構は次のように考えられる。まず，3と 6 a が反応し てマンニッヒ塩基 $14 \mathrm{a}$ が生成する。次いで $14 \mathrm{a}$ は更に $6 \mathrm{a}$ と反応して環化成績体 $12 \mathrm{a}$ に变化する。最後に $12 \mathrm{a}$ がプロトトロピーにより $9 \mathrm{a} に$ 異性化する(式 1)。とこ
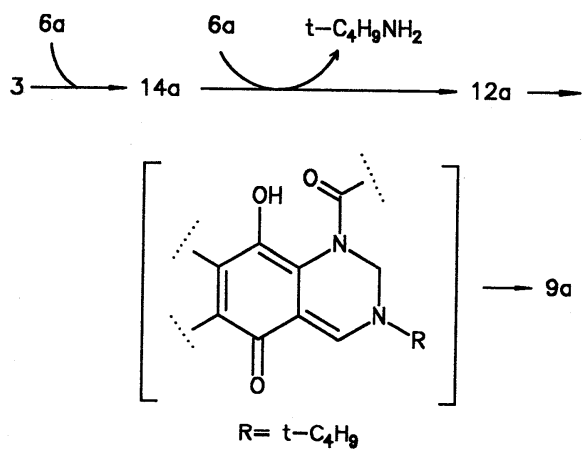

ろで,この反応では $9 \mathrm{a}$ が生成する他に 4 と $15 \mathrm{a}$ が副 生した。これは遊離した $t$-ブチルアミンにより $9 \mathrm{a} の$<smiles>[R]N1CC2=C(C(=O)c3c(c(O)c(C)c4c3C(=O)C(C)(C)O4)C2=O)N(C(C)=O)C1</smiles>

12<smiles>[R]N1Cc2c(c(O)c3c4c(c(C)c(O)c3c2O)C(C)C(=O)OC(C)(C)C4)N(C(C)=O)C1</smiles>

13

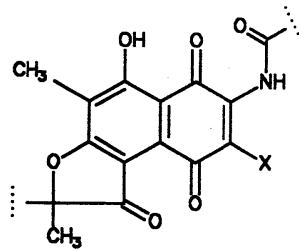

14: $\mathrm{X}=\mathrm{CH}_{2} \mathrm{NHR}$

15: $X=C H=N R$

16: $\mathrm{X}=\mathrm{CH}_{2} \mathrm{NR}_{2}$

17: $\mathrm{X}=\mathrm{CHO}$<smiles>[X]c1c(NC(C)=O)c(O)c2c(O)c(C)c3c(c2c1O)C(=O)C(C)(C)O3</smiles>

18: $\mathrm{X}=\mathrm{CH}=\mathrm{NR}$

19: $\mathrm{X}=\mathrm{CH}_{2} \mathrm{NHR}$

20: $\mathrm{X}=\mathrm{CH}_{2} \mathrm{NR}_{2}$

21: $X=\mathrm{CHO}$
Fig. 3

一部がアミノリシスを受けて $18 \mathrm{a}$ となり, 次いで $18 \mathrm{a}$ と残存している 3 との間の redox 反応により 4 と $15 \mathrm{a}$ が副生したと考えられる。事実, 3 の存在下 $9 a$ に $t$-ブ チルアミンを作用させると 4 と $15 \mathrm{a}$ が生成した。なお, 第一級アミンによる 9 から 18へのアミノリシスは特に $\mathrm{H}_{2} \mathrm{O}$ の存在下容易に進行する (4.1. 参照)。3 と種々の 6 との反応結果を表 1 にまとめた ${ }^{17)}$ 。 $6 \mathrm{c}$ ｅ場合，4 と $13 \mathrm{c}$ ～eが主成績体であった。これはイミニウム結合に 対する $6 \mathrm{c} \sim \mathrm{e}$ の還元作用に起因する (4.2. 参照)。

ところで，12に見られるプロトトロピーによるキノ ン型リファマイシンからヒドロキノン型リファマイシン への異性化は 14 の場合にも見られ，14は15と 19 に不 均化する ${ }^{17)}($ 式 2)。

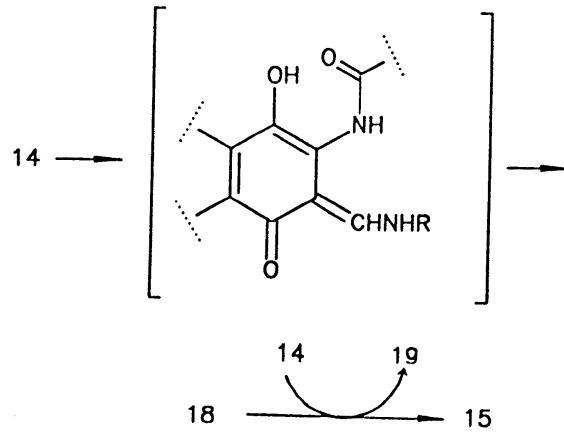

また Maggi らは $16 \mathrm{~d}$ が酸性条件下 $16 \mathrm{~d}, 17,20 \mathrm{~d}, 21$ 
Table 1 Reaction of 3 with 6.

\begin{tabular}{lccc}
\hline \multirow{2}{*}{$\frac{6}{\mathrm{R}}$} & \multicolumn{2}{c}{ Reaction Conditions ${ }^{\mathrm{a}}{ }^{2}$} & Yield (\%) \\
\cline { 2 - 3 } & $\left({ }^{\circ} \mathrm{C}\right)$ & $(\mathrm{hr})$ & \\
\hline$t$-butyl & 63 & 1.5 & $9 \mathrm{a}: 38$ \\
$t$-amyl & 40 & 3.5 & $9 \mathrm{~b}: 48$ \\
methyl & r.t. & 48 & $9 \mathrm{c}: 2$ \\
ethyl & r.t. & 48 & $9 \mathrm{~d}: 2$ \\
cyclohexyl & r.t. & 3.5 & $9 \mathrm{e}: 4$ \\
\hline
\end{tabular}

a) Pryidine was used as a solvent.

の混合物へと変化することを認め，この機構として，ま ず $16 \mathrm{~d}$ が酸化的不均化により $20 \mathrm{~d}$ と 22 に変化すると 考えた ${ }^{19)}($ 式 3 )。しかしこの場合にも, 先のプロトトロ

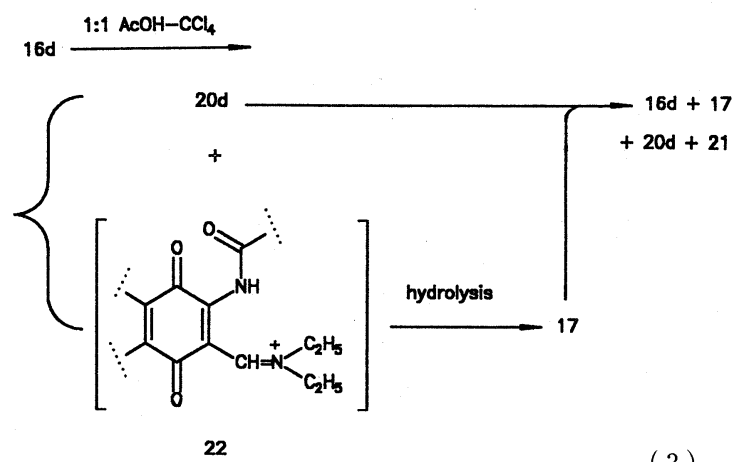

ピーと同じく $16 \mathrm{~d}$ がまず 23 へ異性化すると考えること で説明できる(式 4$)$ 。

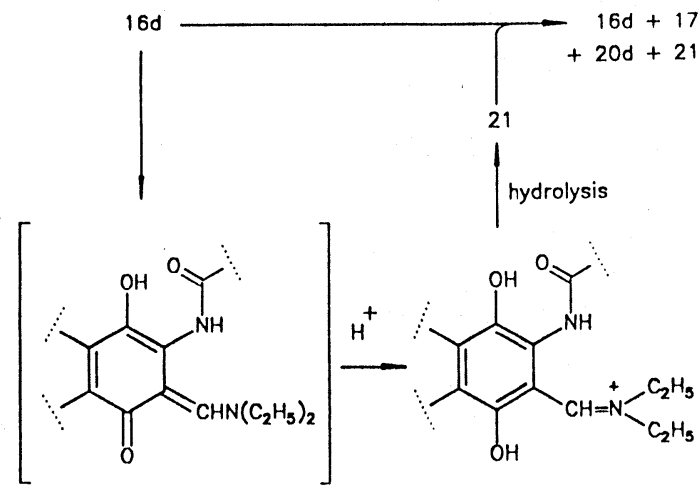

23

なお, Gianantonio らは $\mathrm{MnO}_{2}$ 共存下, 3 にホルムア ルデヒドとホルムアルデヒドに比し過剩量の $t$-ブチル アミンとを作用させて $15 \mathrm{a}$ を高収率で得た ${ }^{20)}$ 。3から $12 \mathrm{a}$ を経て生成した $9 \mathrm{a}$ が $\mathrm{H}_{2} \mathrm{O}$ の)存在下 (Gianantonio ら
はホルムアルデヒドとしてホルマリンを用いているので 反応系には $\mathrm{H}_{2} \mathrm{O}$ が含まれている) $t$-ブチルアミンにより アミノリシスを受けて $18 \mathrm{a} に な り ，$ 最後に $\mathrm{MnO}_{2}$ で酸 化されて $15 \mathrm{a}$ が生成すると考えられる。

\section{3-ホルミルリファマイシン S (17) と 第二級アルキルアミンとの反応 ${ }^{21)}$}

先に述べたプロトトロピーは二重結合を介しても進行 する。即ち, 17 に第二級アルキルアミンを作用させると， 24〜28 が生成した(表 2 )。イミニウム塩 29 の生成, 29 のプロトトロピーによる 30 への異性化，そして 30 の閉 環により生成すると考えられる(式 5 )。30の存在は, 17 とジエチルアミンあるいはジブチルアミンとの反応 で 21 と $31\left(\mathrm{R}^{\prime \prime}=\mathrm{CH}_{3}\right.$ あるいは $\left.\mathrm{C}_{3} \mathrm{H}_{7}\right)$ が副生すること, 17 とオク夕メチレンイミンとの反応で $31\left(\mathrm{R}^{\prime \prime}=\mathrm{CH}_{2}\right.$ $\left(\mathrm{CH}_{2}\right)_{5}-\mathrm{CHO}$, 収率 $\left.5.5 \%\right)$ が得られることから支持され る。

ところで，24 と 25 には $2^{\prime}$ 位の不斉炭素に基づく $2 つ$ のエピマーが可能であるが，実際には一方のエピマー (2'S 体) しか生成しなかった。一方，26２8の場合，2 つのエピマー $\left(2^{\prime} R\right.$ 体 32 と $2^{\prime} S$ 体 33) が生成した。26〜 28 の $\left(2^{\prime} R\right)$-エピマー 32 と $\left(2^{\prime} S\right)$-エピマー 33 の収率は, 26 と 27 においては前者のほうが, 28 においては後者の ほうが高い。また，24と 25 においては $\left(2^{\prime} S\right)$-エピマー しか生成しない。これらは次のように説明することがで きる。シクロアルカンからシクロアルケンが生成すると き二重結合の立体配置は環員数によって影響され，7員
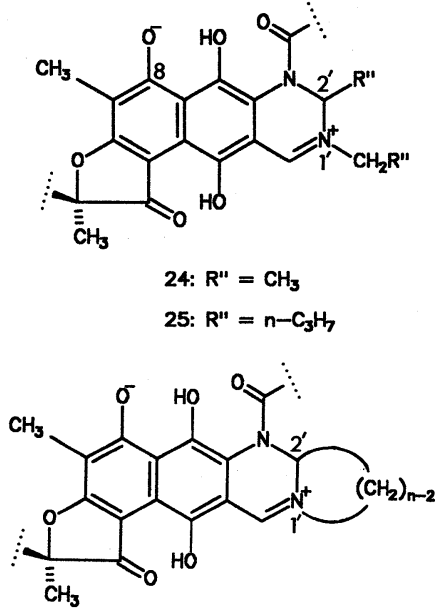

26: $n=7$
27: $n=8$

Fig. 4 
Table 2 Dihydropyrimidorifamycins 24 28 from 3-formylrifamycin S (17) and secondary amines.

\begin{tabular}{|c|c|c|c|}
\hline \multirow{2}{*}{ Amine (mol ratio to 17 ) } & \multicolumn{2}{|c|}{ Reaction Conditions $^{a)}$} & \multirow{2}{*}{ Yield (\%) } \\
\hline & Solvent & Time(min) & \\
\hline Diethylamine (5.9) & $\mathrm{AcOEt}$ & 25 & $\left(2^{\prime} S\right)-24: 15$ \\
\hline Diethylamine $(2.0)^{\mathrm{b})}$ & $\mathrm{CHCl}_{3}$ & 30 & $25-O-$ deacetyl- $\left(2^{\prime} S\right)-24: 17$ \\
\hline Dibutylamine (6.5) & $\mathrm{AcOEt}$ & 40 & $\left(2^{\prime} S\right)-25: 62$ \\
\hline Hexamethyleneimine (2.2) & $\mathrm{CHCl}_{3}$ & 40 & $\left(2^{\prime} R\right)-26: 17,\left(2^{\prime} S\right)-26: 6$ \\
\hline Heptamethyleneimine (1.0) & $\mathrm{CHCl}_{3}$ & 40 & $\left(2^{\prime} R\right)-27: 42,\left(2^{\prime} S\right)-27: 4$ \\
\hline Octamethyleneimine (2.5) & $\mathrm{CHCl}_{3}$ & 15 & $\left(2^{\prime} R\right)-28: 3,\left(2^{\prime} S\right)-28: 42$ \\
\hline
\end{tabular}

a) The reaction was carried out at r.t.

b) The 25-O-deacetyl derivative of 17 was used.

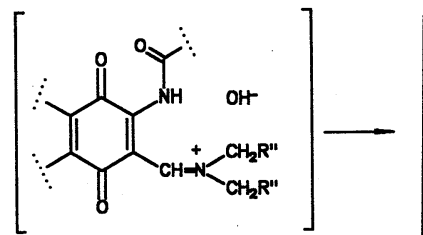

29

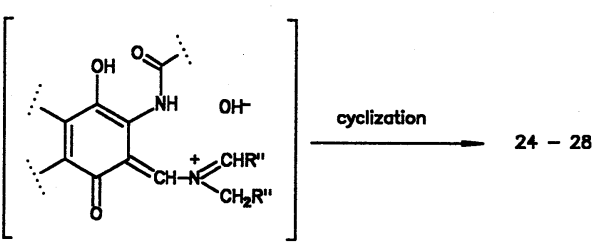

30 hydrolysis

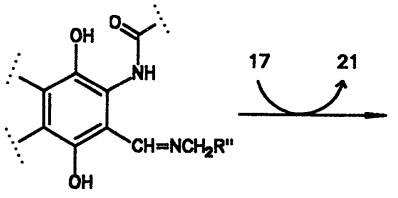<smiles>CC1=C(C)C(=O)C(NC(C)(C)C)=C(C=[V])C1=O</smiles>

31
環および 8 員環の場合にはシスオレフィンが，9員環の 場合にはトランスオレフィンが有利に生成する ${ }^{22)}$ 。30
の生成においても同様に考えると，26と 27 の中間体と しては 34 が，また 28 の中間体としては 35 が有利に生

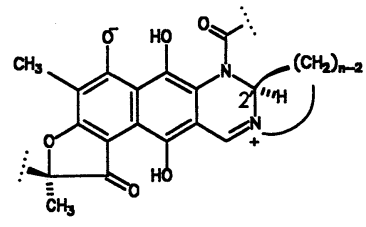

32: (2'R)-epimer

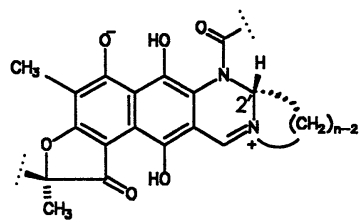

33: (2's)-opimer

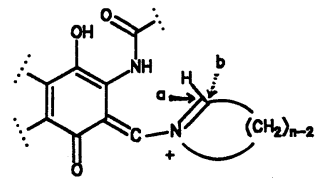

34

$(n=7$ or 8$)$

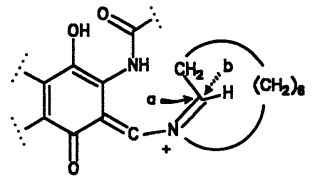

35

Fig. 5

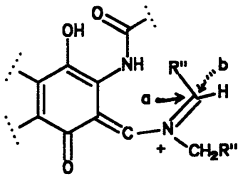

36 
成する。24と 25 に関しては，35の場合と同様に 36 が 有利に生成すると考えられる。34 36 が閉環する場合, アミドの窒素原子のイミニウム炭素への付加方向として はイミニウム炭素の手前から ( $\mathrm{a}$ 方向) と背後から ( $\mathrm{b}$ 方 向)の 2 通りがある。これらの方向は, イミニウム炭素 がクロモフォア平面の上と下のどちら側に位置するかに よって決まり, 下側に位置するときは a 方向に, 上側に 位置するときはb 方向に決まる。ところでアンサ鎖はク ロモフォア平面の上側に位置している。従って, イミニ ウム炭素がクロモフォア平面の上側に位置するコンホ メーションはアンサ鎖との立体反発のため不利になり， 付加方向の割合は $\mathrm{b}$ 方向よりも $\mathrm{a}$ 方向のほうが多くなる と予想される。以上から, 26 と 27 の場合には $\left(2^{\prime} R\right)-$ 工 ピマー 32 が, また 28 の場合には $\left(2^{\prime} S\right)$-エピマー 33 が 多く生成すると考えられる。24 と 25 の場合には $\left(2^{\prime} S\right)$ エピマーしか生成しない。これは36のイミニウム炭素 が，置換基 $\mathrm{R}^{\prime \prime}$ とアンサ鎖との間の大きな立体反発によ ククロモフォア平面の上側に位置することが極めて不利 になるためと考えられる。

\section{4. ホルマリン共存下における 3-ホルミルリファ マイシン SV $(21)$ と第一級アルキルアミンとの 反応23)}

4.1. ジヒドロピリミジニウム環形成反応ささきに述 ベたジヒドロピリミドリファマイシン (2. 参照) は, 21 にシッフ塩基を作用させても生成する。例えば, 21 に $6 \mathrm{c}$ をピリジン中, $40^{\circ} \mathrm{C}$ で 2 時間作用させると 21 の木 ルミル基とアミド基, および $6 \mathrm{c}$ との間でジヒドロピリ ミジニウム環形成反応が進行して $9 \mathrm{c}$ (収率 $51 \%$ )が得ら れた。また， $N$-メチレンーtーオクチルアミンを作用させ
ると, $9 \mathrm{~h}$ (収率 $88 \%$ ) が得られた。以上の反応はホルマ リン共存下に第一級アルキルアミンを作用させても進行 する。但しこの場合，ホルマリンは第一級アルキルアミ ンに比して過剰量を用いる必要がある。逆の量的関係で は環形成反応は進行しない。これは, 水の存在下, 第一 級アルキルアミンにより 9 が 18 へと容易にアミノリシ スされることによる。21にホルマリンと種々の第一級 アルキルアミンとを作用させて 9 を得た結果を表 3 にま とめた。

4.2. イミニウム結合の還元さきの反応で $\alpha$ 位に 1 ～3 個の水素原子を有する第一級アルキルアミンあるい はこのようなアミンから誘導された 6 を用いると 9 のイ ミニウム結合が還元され，13が副生する。これに対し て $t$-ブチルアミンや $t$-オクチルアミンを用いた場合に は13は副生しない。このことから還元にはホルムアル デヒドとアミンとから生成する還元性物質のアミン残基 の $\alpha$ 位の水素原子が使われていると考えられたが，以 下にのべるようにホルムアルデヒド由来の水素原子であ ることがわかった。

21 に重ホルマリンと $n$-オクチルアミンとを反応させ たのち $\left(72^{\circ} \mathrm{C}, 2.25 \mathrm{hr}\right)$, 酸加水分解して 37 を得た。一 方， $n$-オクチルアミン存在下， 21 に $\mathrm{NaBH}_{4}$ を作用させ て19fを得た。19fの ${ }^{1} \mathrm{H}-\mathrm{NMR}$ スペクトル $\left(\mathrm{CDCl}_{3}\right.$ 溶液 $)$ は $\delta 3.76(1 \mathrm{H}, \mathrm{d}, J=12 \mathrm{~Hz})$ および $\delta 4.20(1 \mathrm{H}, \mathrm{d}, J=$ $12 \mathrm{~Hz})$ にメチレンプロトン $\left(3-\mathrm{CH}_{2} \mathrm{NHC}_{8} \mathrm{H}_{7}\right)$ に䚻属される 2 個のダブレットを示した。37ではこのうち $\delta 4.20$ の ダブレットが消失し， $\delta 3.76$ のダブレットはシングレッ トに変化していた。これは，イミニウム結合の還元にホ ルムアルデヒド由来の水素原子が使われていること，ま た還元は立体選択的に進行していることを示している。

Table 3 Dihydropyrimidorifamycins 9 from 3-formylrifamycin SV(21), alkylamines, and formalin.

\begin{tabular}{|c|c|c|c|}
\hline \multirow{2}{*}{ Amine } & \multicolumn{2}{|c|}{ Reaction Conditions $^{a)}$} & \multirow{2}{*}{$\begin{array}{c}\text { Yield } \\
(\%)\end{array}$} \\
\hline & $\left({ }^{\circ} \mathrm{C}\right)$ & $(\mathrm{hr})$ & \\
\hline$t$-Butylamine & 42 & 3 & $9 a: 69$ \\
\hline Methylamine & 42 & 3.5 & $9 c: 68$ \\
\hline Ethylamine & 66 & 0.33 & $9 d: 90$ \\
\hline Cyclohexylamine & 42 & 3 & $9 \mathrm{e}: 85$ \\
\hline$n$-Octylamine & r.t. & 4.75 & $9 f: 56$ \\
\hline$s$-Octylamine & r.t. & 5 & $9 \mathrm{~g}: 70$ \\
\hline$t$-Octylamine & 43 & 4.5 & $9 h: 83$ \\
\hline 1-Adamantylamine & r.t. & 2.75 & $9 \mathrm{i}: 90$ \\
\hline 1,1-Dimethyl-2-hydroxyethylamine & 45 & 3 & $9 \mathrm{j}: 78$ \\
\hline
\end{tabular}

a) Pyridine was used as a solvent. 
<smiles>[Y]C(=O)Nc1c(C([2H])([2H])NCCC)c(O)c2c3c(c(C)c(O)c2c1O)OC(C)(C)C3=O</smiles>

37<smiles>CC(=O)Nc1c(C=[W])c(O)c2c3c(c(C)c(O)c2c1O)[C@@]1(C)O[C@]1(C)C3=O</smiles>

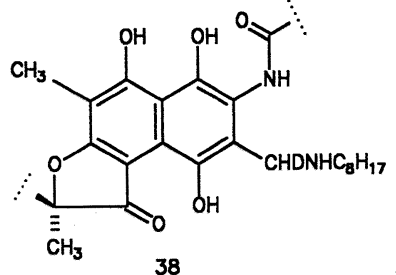<smiles></smiles>

Fig. 6

還元が立体選択的に進行するのは, 還元性物質(例えば 6 には還元作用があることが報告されている $\left.{ }^{24)}\right)$ がアン サ鎖との立体障害のため一方向 $(\alpha$ 面) からしかイミニウ ム炭素に接近できないことによると考えられる。なお, $9 \mathrm{f}$ に $\mathrm{NaBD}_{4}$ を作用させても同様の立体選択的還元反応 が進行する。ところで， $n$-オクチルアミン存在下, 21 に $\mathrm{NaBD}_{4}$ を作用させると $\delta 3.76$ と $\delta 4.20$ にシング レットを示す 38 が得られた。39と 40 の 2 種のコンホ メーションの存在により見かけ上非立体選択的に還元反 応が進行したと考えられる。 $\alpha$ 位に水素原子がないアミ ンの場合にイミニウム結合が還元されないのは, 還元性 物質のアミン由来の残基と 9 の置換基 $\mathrm{R}$ との間の立体障 害のため, 還元性物質がイミニウム炭素に接近できない ことによると考えられる。

\section{3-ホルミルリファマイシン S (17)と} シッフ塩基との反応 25

さきに述べたジヒドロピリミジニウム環形成反応 (4. 参照) は17でも進行する。即ち, 17 の酢酸エチル溶液 にシッフ塩基 $6 \mathrm{a}, 6 \mathrm{c}$ あるいは $N$-メチレンーt-オクチ ルアミンを加えると 17 は消失した。次いでアスコルビ ン酸を加えると黄褐色であった溶液が直ちに深青色に変

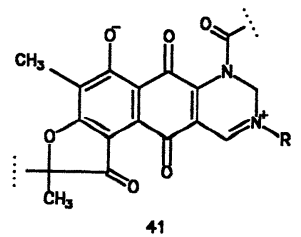

Fig. 7

Table 4 The reaction of 3-formylrifamycin S (17) with Schiff bases following by reduction with $\mathrm{L}^{-}$ascorbic acid.

\begin{tabular}{ccc}
\hline Schiff Base & Time $(\mathrm{min})^{\mathrm{a})}$ & Product : Yield(\%) \\
\hline $6 \mathrm{a}$ & 10 & $9 \mathrm{a}: 62$ \\
$6 \mathrm{c}$ & 20 & $9 \mathrm{c}: 50$ \\
b) & 10 & $9 \mathrm{~h}: 37$ \\
\hline
\end{tabular}

a) The reaction was carried out at r.t. in AcOEt.

b) $N$-methylene-t-octylamine.

化し，それぞれ9a，9c および $9 \mathrm{~h}$ が生成した。41 が生 成し, 次いで 9 へ還元されたと考えられる。結果を表 4 にまとめた。しかし次に述べるように, シッフ塩基に類 似のアミノメチルエーテルを作用させるとマンニッヒ反 応が進行した。

\section{3-ホルミルリファマイシン S (17) と アミノメチルエーテルとの反応 ${ }^{26)}$}

酢酸エチル中, $17 に 3 〜 4.5$ 倍モルのアミノメチル エーテル $42 \mathrm{~d}$ あるいは $42\left(\mathrm{NR}_{2}=1\right.$-pyrrolidinyl)を作用

$\mathrm{CH}_{3} \mathrm{OCH}_{2} \mathrm{NR}_{2}$

42<smiles>CC(=O)Nc1c(O)c(I)c(I)c(O)c1C1CCCC1</smiles>

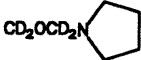

43

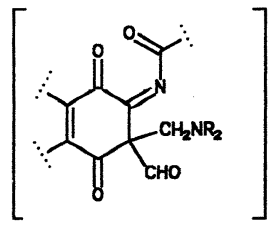

Fig. 8 
Table 5 The reaction ${ }^{\text {a) }}$ of 3 -formylrifamycin S (17) with aminomethyl ether following by reduction with L-ascorbic acid.

\begin{tabular}{clc}
\hline $\begin{array}{c}\text { Aminomethyl Ether } \\
\text { (mole ratio to 17) }\end{array}$ & $\begin{array}{l}\text { Time } \\
(\mathrm{hr})\end{array}$ & Product : Yield(\%) \\
\hline $42 \mathrm{~d}(4.5)$ & 1 & 20d : 40 \\
b)(3.0) & 0.5 & c) $: 51$ \\
\hline
\end{tabular}

a) The reaction was carried out at r.t. in AcOEt.

b) $42\left(\mathrm{NR}_{2}=1\right.$-pyrrolidinyl $)$

c) $20\left(\mathrm{NR}_{2}=1\right.$-pyrrolidinyl $)$

させるとそれぞれ 16 dあるいは $16\left(\mathrm{NR}_{2}=1\right.$-pyrrolidinyl)が生成した。これらは不安定であるため, アスコル ビン酸で還元して $20 \mathrm{~d}$ および $20\left(\mathrm{NR}_{2}=1\right.$-pyrrolidinyl) に導いた。結果を表 5 にまとめた。43の場合には重水 素化された 44 が得られることから，17とアミノメチル エーテルとの間にマンニッヒ反応が進行して 45 が生成 し，次いでホルミル基がギ酸メチルとして脱離すると考 えられる。

\section{5. おわりに}

以上リファマイシンの反応性に関して筆者らの知見を 紹介した。この中でリファマイシンの反応性についてそ の一端を明らかにすることができたものと考えている。

なお，本研究を進めるにあたり多々ご指導頂きました 岡山理科大学大饗茂教授に感謝致します。

(平成元年 2 月 28 日受理)

\section{文献}

1) P. Sensi, P. Margalith, M.T. Timbal, Farmaco Ed. Sci., 14, 146 (1959); G.G. Gallo, L. Chiesa, P. Sensi, Anal. Chem., 34, 423 (1962) ; P. Sensi, Rev. Infect. Dis., 5, S 463 (1983)

2) P. Sensi, R. Ballotta, A.M. Greco, Farmaco Ed. Sci., 15, 228 (1960)

3) P. Sensi, M.T. Timbal, G. Maffii, Experientia, 16, 412 (1960)

4) P. Sensi, R. Ballotta, A.M. Greco, G.G. Gallo, Farmaco Ed. Sci., 16, 165 (1961)

5a) W. Oppolzer, V. Prelog, P. Sensi, Experientia, 20, 336 (1964) ; J. Leitich, W. Oppolzer, V. Prelog, ibid., 20, 343 (1964)

b) W. Oppolzer, V. Prelog, Helv. Chim. Acta, 56, 2287 (1973)

6) M. Brufani, W. Fedeli, G. Giacomello, A. Vaciago, Experientia, 20, 339 (1964); M. Brufani, S. Cerrini, W. Fedeli, A. Vaciago, J. Mol. Biol., 87, 409 (1974)

7) P.M. Gadret, M. Goursolle, J.M. Leger, J.C.
Colleter, Acta Crystallogr., Sect. B, 31, 1454 (1975) ; S.K. Arora, ibid., 37, 152 (1981) ; M. Brufani, L. Cellai, S. Cerrini, W. Fedeli, A. Segre, A. Vaciago, Mol. Pharmacol., 21, 394 (1982) ; S.K. Arora, ibid., 23, 133 (1983) ; S.K. Arora, P. Main, J. Antibio., 37, 178 (1984); M. Brufani, L. Cellai, S. Cerrini, W. Fedeli, E. Marchi, A. Segre, A. Vaciago, ibid., 37, 1623 (1984); S.K. Arora., J. Med. Chem., 28, 1099 (1985)

8) V. Prelog, W. Oppolzer, Helv. Chim. Acta, 56, 2279 (1973)

9) E.J. Corey, T. Hase, Tetrahedron Lett., 1979, 335 ; E. J. Corey, G. Schmidt, ibid., 1979, 2317 ; M. Nakata, Y. Ikeyama, H. Takao, M. Kinoshita, Bull. Chem. Soc. Jpm., 53, 3252 (1980) ; M. Nakata, T. Sakai, K. Tatsuta, M. Kinoshita, ibid ., 54, 1743 (1981) ; M. Nakata, H. Takao, Y. Ikeyama, T. Sakai, K. Tatsuta, M. Kinoshita, ibid ., 54, 1749 (1981); M. Nakata, H. Enari, M. Kinoshita, ibid., 55, 3283 (1982) ; S. Masamune, B. Imperiali, D.S. Garrey, J. Am . Chem. Soc., 104, 5528 (1982); S. Hanessian, J.-R. Pougny, I.K. Bossenkool, ibid . , 104, 6164 (1982) ; idem., Tetrahedron, 40, 1289 (1984); W.C. Still, J.C. Barrish, J. Am . Chem. Soc., 105, 2487 (1983) ; B. Fraser-Reid, L. Magdzinski, B. Molino, ibid., 106, 731 (1984) ; A.V. Rama Rao, J.S. Yadav, V. Vidyasagar, Chem. Commun., 1985, 55 ; P.A. Bartlett, J. Myerson, J. Am. Chem. Soc., 100, 3950 (1978)

10) K.A. Parker, J.J. Petraitis, Tetrahedron Lett ., 22, 397 (1981) ; T.R. Kelly, M. Behforouz, A. Echavarren, J. Vaya, ibid ., 24, 2331 (1983) ; M. Nakata, M. Kinoshita, ibid . , 25, 1373 (1984); M. Nakata, S. Wada, K. Tatsuta, M. Kinoshita, Bull. Chem. Soc.Jpn., 58, 1801 (1985)

11) H. Nagaoka, W. Rutsch, G. Schmid, H. Iio, M.R. Johnson, Y. Kishi, J. Am. Chem. Soc, 102, 7962 (1980) ; H. Iio, H. Nagaoka, Y. Kishi, ibid., 102, 7967 (1980) ; H. Nagaoka, G. Schmid, H. Iio, Y. Kishi, Tetrahedron Lett., 22, 899 (1981); H. Nagaoka, Y. Kishi, Tetrahedron, 23, 3873 (1981) ; Y. Kishi, Pure Appl. Chem., 53, 1163 (1981)

12) N. Maggi, R. Pallanza, P. Sensi, Antimicrob. Agents Chemother., 1965, 765 ; P. Sensi, N. Maggi, S. Furesz, G. Maffii, ibid., 1966, 699; 住木 諭介，抗生物質 補遺 I, pp.1185-1207 (1970) 東 京大学出版会; 住木諭介, 抗生物質 補遺 II, pp.1365-1386 (1973) 東京大学出版会; G. Lancini, W. Zanichelli, "Structure-Activity Relationships among the Semisynthetic Antibiotics" (D. Perlman ed.) pp.531-600 (1977) Academic Press, Inc.; M. 
Brufani, "Topics in Antibiotic Chemistry" (P.G. Sammes ed.), Vol.1, pp.91-212 (1977) Ellis Horwood Ltd.

13) V. Arioli, P. Pallanza, S. Furesz, G. Carniti, Arzneim.-Forsch ., 17, 525 (1967) ; R. Pallanza, V. Arioli, S. Furesz, G. Bolzoni, ibid., 17, 529 (1967) ; S. Furesz, R. Scotti, R. Pallanza, E. Mapelli, ibid., 17, 534 (1967); S. Furesz, Antibiot. Chemother., 16, 316 (1970)

14）レオナルド・マルジリ，カルミネ・レナート・パ スカルチ, 日特開 昭 50-41,897;50-42,021 (1975)

15）塚本悟郎，相川法男，田口雅裕，日本薬学会第 100 年会, 東京, 講演要旨集, p.207 (1980)

16) G. Tsukamoto, N. Aikawa, M. Taguchi, Chem. Lett. , 1979, 1313

17) M. Taguchi, N. Aikawa, G. Tsukamoto, Bull. Chem. Soc.Jpn., 61, 2431 (1988)

18) P. Ferrari, G.G. Gallo, Farmaco Ed. Sci . , 30, 676 (1975)
19) N. Maggi, G.G. Gallo, P. Sensi, Farmaco Ed. Sci., 22, 316 (1967)

20）アナクレト・ジアナントニオ, アルド・ファブルッ チ, セルジオ・サツエルドチ, アレアンドラ・ソ ウツ才, 日特公 昭 47-23,303; 昭 47-44,757 (1972)

21) M. Taguchi, N. Aikawa, G. Tsukamoto, Chem . Pharm. Bull., 32, 4388 (1984)

22) E.L. Eliel, "Stereochemistry of Carbon Compounds" (1962) McGraw-Hill Book Company, Inc. [島村, 右田, 徳丸, 吉田訳, 炭素化合物の立体化学, p.295 (1965) 東京化学同人]

23) G. Tsukamoto, M. Taguchi, N. Aikawa, Chem. Pharm. Bull., 28, 2309 (1980)

24) H. Mohrle, V. Scharf, Pharmazie, 33, 784 (1978)

25）塚本悟郎, 相川法男, 田口雅裕, 内海 勇, 日特 開 昭 56-16,487 (1981)

26）相川法男，田口雅裕，塚本悟郎，日本薬学会第 101 年会, 熊本, 講演要旨集, p.532 (1981)

\section{本 誌 広 告 料 金}

\begin{tabular}{|c|c|c|c|c|c|}
\hline 表 紙 & 2 & 1 頁 & 80,000 円 & 後 付 & 50,000 円 \\
\hline 表 紙 & 3 & 1 頁 & 60,000 円 & " $1 / 2$ 頁 & 30,000 円 \\
\hline 紙 & 4 & 1 頁 (2 色) & 100,000 円 & 緅 込 (1 枚) & 100,000 円現物持込 \\
\hline 文目次 & & 頁 & 35,000 円 & & (62. 1. 改訂実施) \\
\hline
\end{tabular}

詳細は下記一手取り扱い社へご照会下さい。

（株）共 栄 通 信 社

本 社 $\mathbf{T} 104$ 東京都中央区銀座 8-2-1（新田ビル） Tel. 03-572-3381 (代)

大阪支社 $\bar{\top} 530$ 大阪市北区西天満 3-6-8（笹屋ビル） Tel. 06-362-6515 (代) 